\title{
CONTROLLING THE BUREAUCRACY OF THE ANTIPOVERTY PROGRAM
}

\author{
VICTOR G. RoseNBLUM*
}

Roscoe Pound's view of law as an instrument for satisfaction of social wants retains significance as both a rallying ground and problem maze for today's reformers:

I am content to think of law as a social institution to satisfy social wants-the claims and demands and expectations involved in the existence of civilized society-by giving effect to as much as we may with the least sacrifice, so far as such wants may be satisfied or such claims given effect by an ordering of human conduct through politically organized society. For present purposes I am content to see in legal history the record of a continually wider recognizing and satisfying of human wants or claims or desires through social control; a more embracing and more effective securing of social interests; a continually more complete and effective elimination of waste and precluding of friction in human enjoyment of the goods of existence-in short, a continually more efficacious social engineering. ${ }^{1}$

As rallying ground, Pound's "contentment" calls attention to law as satisfier of social wants more than of individual wills. As problem maze, it demands choice from among competing claims, demands, and expectations without offering certainty of outcome. What programs, procedures, or controls give "effect to as much as we may with the least sacrifice"? What are the ascertainable relationships between degree of sacrifice and degree of want satisfaction? Since all social wants cannot be satisfied simultaneously, what criteria shall be invoked to determine the rank ordering of priorities?

We know that stratification occurs in every social structure, that some roles receive different rewards or sanctions from others. What are our standards for such differential distributions? Are they apportioned according to need, power, values, interests, community censensus, majority opinion, constitutional mandate, or some combination of these? Only recently have we begun realistically and systematically to face such problems, let alone find national agreement on them. At the same time, the majesty of aspiration that underlies the war on poverty requires that action be taken and choices made, even if the data for evaluation and prediction are still amorphous.

Dissensus over some details of allocation and administration of hundreds of

- A.B. I945, LL.B. I948, Columbia University; Ph.D. I953, University of California at Berkeley. Professor of Political Science and Law, Northwestern University; Director of the Russell Sage Program in Law and the Social Sciences at Northwestern University; Editor-in-Chief, Administrative Lasu Review. Author, LAw as a Political Instrument (r955); Co-author, The Uses of Power (1962). Contributor of articles to professional journals.

${ }^{1}$ Roscoe Pound, AN Introduction to the Philosophy of Law 47 (I922). 
millions of dollars by myriad bureaucratic structures to enhance individual and community welfare is inevitable. The purpose of the present article is not to delineate or take sides in the emergent conflicts, but to examine the institutions and methods that have been proposed to keep the expanding power apparatus that copes with poverty accountable both to the individuals with whom it deals directly and to the public generally. As a representative of one of the community action programs has pointed out, ". . . the range of publicly provided resources has become so extensive that the poor in this society can only survive if they learn how to maneuver successfully within the bureaucracies that control these resources."

What are the instruments of accountability, redress, revision, and reform ? ${ }^{3}$ Are appeals to the courts more or less available and effective than appeals to one's congressman, precinct captain, or interest group? Let us examine a number of devices - some of them proposed importations and others currently in use. In the category of importations are the French Conseil d'Etat, the British Citizens' Advice Bureaus, and, glossiest of all, the Swedish Ombudsman.

\section{The Consent d'Etat}

The Conseil d'Etat, a "reliable and virile guardian of individual rights," offers

\footnotetext{
${ }^{2}$ Mogulof, Involving Low-Income Neighborhoods in Antidclinquency Programs, Social Work, Oct. I965, p. $5 \mathrm{I}$.

Two recent but unconnected works are valuable in developing criteria for accountability. Charles Reich of Yale Law School has summarized basic standards for decision making that have come through experience and legal development to represent a fundamental conception of fairness; and David Apter of the University of California has applied his expertise on the politics of emerging societies to postulate conditions for the emergence of democratic society. Reich sets forth cight standards of fairness:
}

"(I) The rules which are to furnish the standard of decision should be clearly formulated in advance of any action; (2) the rules should be available to the public; (3) every action should begin with actual notice of the proposed action and a full statement of the basis for it; (4) the relevant facts should be determined in a proceeding at which the person or company affected can know the evidence and have an opportunity to rebut it; factual findings should not be based on hearsay or secret evidence known only to the agency; (5) the person or company should have the right to be represented by counsel; (6) there should be a distinct separation between those officials who investigate and initiate action and those who find the facts and make the decision; the latter officials should be subject to different authority than the former and free of any of the atmosphere in which the action was begun; (7) the decision, once made, should be accompanied by findings and reasons; (8) there should be opportunity for review of the decision within the agency, and, ultimately, in the courts."

Reich, Individual Rights and Social Welfare: The Emerging Legal Isstues, 75 YALE L.J. 1245, 1252 (1965). Apter believes that the conditions under which the transition to and functioning of democracy become possible are:

I. "Privacy must be a consummatory value." He secs the desire for privacy in modernizing and industrializing societies as a reaction to the growing visibility of life in schools, factories, and other public places. 2. "Authority problems must be transformed into equity problems." Modernization and industrialization can reach the point where inequality and other problems of distributive justice threaten the continuity of authority. When this occurs, mechanisms for establishing equity are necessary as a basis for solidarity. 3. "Information must be available from a variety of sources including frce public communication media, opposition parties, and the like." 4. The means of maintaining equity, accountability, and practical realism are "the constant translation of value conflict into interest conflict," conciliar control over the executive, formalized opposition, and popular sovereignty expressed through universal suffrage and periodic elections. David Apter, The Politics of Modernization 455-56 (1965).

- Henry J. Abraham, The Judicial Process 241 (1962). 
a simple and inexpensive procedure for obtaining review of administrative action, in which the government itself takes the responsibility for investigating the facts and the law pertinent to the complainant's petition. After the plaintiff makes a summary statement of the facts and the relief sought, his request may lead either to proceedings to annul the administrative act in question through invocation of the ultra vires or abuse of power principles, or to proceedings requiring payment of money damages or other affirmative action. The complainant may choose to be represented by counsel; but he need not, and in many instances does not, retain counsel.

An especially appealing feature of the Conseil d'Etat is that it places on the government both liability for fault and liability for creation of unjustifiable risk as well. Thus, redress is available not only against improper administrative action but also against nominally legal action by an agency that operates unequally and unjustly on a citizen in practice. The government bears the cost of equalizing the burdens without necessity for passage of a private bill by the legislature. This has led analysts like Professor Abraham to observe that ". . . in effect, the droit administratif is developing in the direction of absolute liability to ensure equitable sharing among all citizens of the burden of government action."

Another reason for enthusiasm over the Conseil d'État's role is its recognition of administrative law as a broad-based discipline encouraging systematic analysis within a unified framework of key public law problems. ${ }^{6}$ It facilitates the perception of issues of administrative law in such emergent areas as government contracts and responsibilities and immunities of government officials. Professor W. Friedmann has hailed the development of administrative courts alongside the common law courts as a necessary recognition of the duality of the legal system in order to develop "a healthy balance between the needs of administration in the modern welfare state and the essential rights of the citizen."7

Even if one discounts such academic enthusiasm, the trends and refinements in administrative court systems in countries like France and Germany have been impressive. Administrative disputes are submitted in the first instance to tribunals separated from the administrators who have been challenged. Appeals can be taken on fact and law, and the final decisions of the Conseil d'Etat in France or the Bundesverwaltungsgericht in Germany assure a combination of professional

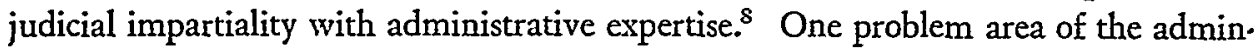
istrative courts, however, concerns enforceability and efficacy of court rulings. Professor Weil of the University of Paris has reminded us recently that the admin-

\footnotetext{
${ }^{5}$ Ibid.

- See gencrally Charles J. Hamson, Executive Discretion and Judicial Control (1954); Bernard Schwartz, French Administrative Iaw and the Common Law World (1954); Cearies E. Freedman, The Conseil d'État in Modern France (196r); Marcei. Waline, Droit Administratif (i957).

7 W. Friedian, Law in a Changing Sochety 413 ( 1959 ).

${ }^{s}$ For a comparison of prevailing Anglo-Saxon and European systems for review of administrative behavior, sec id. at $402-13$.
} 
istrative court judge can annul an illegal decision or order payment of compensation "but he goes no further." In annulling the dismissal of a civil servant, for example, the judge will not order reinstatement, and in annulling a permit refusal, the judge will not force the administrator to grant the permit. ${ }^{9}$ Professor Weil is not enthusiastic about the likelihood of progress in enhancing compliance with judgments. He deems it advisable "to bring pressure to bear on the actual procedure of reaching decisions in the Administration."10

\section{Citizens' Advice Bureaus}

The Citizens' Advice Bureaus (CAB) facilitate accountability through information about the bureaucracy rather than through subjecting it to review. The CABs are not courts or sanctioning agencies of the government; they constitute, rather, an "objective, friendly, and well-informed advisory and information service to the ordinary citizen."11 Established in England in 1939 as a result of a conference on disruption of family life held by the British National Council of Social Service, the $\mathrm{CABs}$ are located in settlement houses, churches, libraries, and casework agencies, and are manned by professional social workers as well as by volunteer help. More than 400 offices located throughout England, Scotland, and Wales advise the general public on how they can best use government welfare services. They also explain the functions and operations of government agencies and acquaint the citizen with his rights so that he can stand up against wrongful government action. Mobile $\mathrm{CABs}$, financed by the Carnegie United Kingdom Trust, visit small towns on market days in order to assist rural populations.

Although CABs are developed on a local basis and are connected only loosely with the central organization, basic policy in providing service is governed by the national CAB council. Publications like the Citizens' Advice Notes Service and the Monthly Information Service Circulars describe local resources and annotate administrative practices. The CABs exercise watchdog functions by giving visibility to hardships and unfair dealings stemming from agency determinations.

Although few CABs retain lawyers to give legal advice directly through the bureaus, their investigations and reports have been instrumental in the revision and bettering of Britain's legal aid program. The charge for filing an application for legal aid is often waived when CABs refer the case. The CABs are credited also with an active role in the confrontation of consumer problems and the drafting of legislation to control high-pressure selling. ${ }^{11}$ The fact that the CABs answer more

\footnotetext{
'Weil, The Strength and Weakness of French Administrative Law, I965 Caмв. L.J. 242.

${ }^{10} \mathrm{Id}$. at 259.

${ }^{11}$ Zucker, Citizens' Advice Bureaus: The British Way, Social Work, Oct. I965, p. 85.

${ }^{12}$ Mildred Zucker, executive director of the James Weldon Johnson Community Center in New York, presented a paper on "Citizens' Advice Bureaus" at the Conference on the Extension of Legal Services to the Poor, in November I964. See Proceedings of the Conference on the Extension of Legni Services to THE POOR III-2x (I965). In updated form, her paper appears in Social Work, Oct. 1965, p. 85. See also National Council of Social Service, Citizens' Advice Bureaus in the Conteiporary
} 
than a million inquiries annually does not measure the quality of their work, but it does indicate widespread use of and confidence in the services they render. The British CABs have also received the compliment of emulation in such countries as Australia, Kenya, and Israel.

\section{The Ombunsman}

Of all the devices available to citizens for redress of grievances against the bureaucracy, the Swedish Justitieombudsman is perhaps the most colorful and has, in any event, received the most attention recently. ${ }^{13}$ Established by the Swedish Constitution of 1809 as Parliament's overseer of administrative behavior, the Ombudsman's sole job is to protect the people from infringement of their rights by proceeding against "those who in the execution of their official duties, have, through partiality, favoritism or other causes, committed any unlawful act or neglected to perform their official duties properly."It The Ombudsman is elected by a committee of forty-eight members of Parliament-twenty-four from each house-

Scene, I959-61, A Report for the National Citizens' Advice Bureau (ig62); John Whyatt, The Crtizen and the Administration: The Redress of Grievances (ig6r); and National. Council of Social Service, Report of the National CAB Committee I962-I964 (London, r964).

${ }^{13}$ An excellent collection of essays has been compiled and edited by Professor Donald Rowat of the University of Toronto and published by the University of Toronto Press: The Ombudsman Cirizen's Defender (Rowat ed. Ig65). Law reviews and political science journals have featured the Ombudsman abundantly. Destined to become the major article on the subject is Walter Gellhorn's The Swedish Ombudsman, 75 YALE L.J. I ( 1965$)$. Professor Gellhorn's worldwide examinations of procedures for settling disagreements with government officials will be published in a Harvard University Press volume in 1966. Other major articles already published by him, which will comprise the substance of this volume, include: The Norwegian Ombudsman, I8 STAN. L. Rev. 293 (1966); Finland's Official Watchman, II4 U. PA. L. Rev. 327 (1966); The Ombudsman in New Zealand, 53 CALIF. L. Rev. II55 (I965); Citizens' Grievances Against Administrative Agencies-the Yugoslav Approach, 64 Mrct. L. Rev. 385 (I966); and Settling Disagreements With Officials in Japan, 79 HARv. L. Rev. 685 (I966). Professors Henry Abraham and Kenneth Davis were early supporters of the importation of the office of Ombudsman into the United States. In Ombudsman in America: Officers to Criticize Administrative Action, 109 U. PA. L. REv. 1057 (196r), Professor Davis endorsed the Ombudsman as an institution that might provide an additional check on the excesses of administrative power. His article was destined to be read primarily by lawyers, whereas Professor Abraham's A People's Watchdog Against Abuse of Power, 20 PuB. Admin. Rev. 152 (1960) was directed toward political scientists and administrators. Abraham saw establishment of the office of Ombudsman as engendering hope of "trust and good will that are so desperately needed today" in relationships between the governed and the governors.

Other informative analyses and commentaries on the Ombudsman include: Aikman, The Neav Zealand Ombudsman, 42 Can. B. Rev. 399 (1964); Anderman, The Swedish Justitieombudsman, Ir AM. J. Comp. L. 225 (1962); Blom-Cooper, An Ombudsman in Britain, r96o Public Law 145; Christenson, The Danish Ombudsman, I09 U. PA. L. Rev. 1100 (196r); Hurwitz, The Danish Parliamentary Commissioner for Civil and Military Government Administration, I958 PuBL.IC LAw 235; Hurwitz, Denmark's Ombudsman: The Parliamentary Commissioner for Civil and Military Government Administration, I961 Wis. L. Rev. I69; Jägerskiöld, The Swedish Ombudsman, rog U. PA. L. Rev. I077 (196r); Jain, Ombudsman in New Zealand, 5 J. INDIAN L. INST. 307 (I963); Pederson, The Danish Parliamentary Commissioner in Action, 1959 PuBLIC LAw II5; Powles, The Citizen's Rights Against the Modern State, and Its Responsibilities to Him, 13 INr'z \& CoMp. L.Q. 76I (I964); Reuss, An "Ombudsman" for America, N.Y. Times, Sept. 13, 1964 (Magazine); Reuss \& Anderson, The Ombudsman: Tribune of the People, Annals, Jan. I966, p. 44; William A. Robson, The Governors and the Governed 22-3I (I964); Rosenthal, The Ombudsman-Swedish "Grievance Man," 24 Pub. Admin. Rev. 226 (I964); Rowat, Ombudsman for North America, 24 PuB. Admin. Rev. 230 (I964).

${ }^{15}$ Swedish CoNst, art. 96. 
to a four-year term. He can be and usually is re-elected, though custom limits him to three terms. Maximum care is taken to insulate the Ombudsman from partisan political pressures. He has no responsibility whatever to the executive and reports only to Parliament. While his annual reports are made to and reviewed by the First Law Committee of Parliament, there are not even remote indications that the Committee in particular or Parliament in general has ever sought to influence negotiations, inquiries, or prosecutions he has undertaken. ${ }^{15}$

One of the most appealing aspects of the Ombudsman's role is its aura of unlimited access. Anyone, any time, can complain to him, and he can proceed against any public official except the Cabinet ministers or the King in council in correcting alleged injustices. There is no requirement of exhaustion of administrative remedies before the Ombudsman's aid is invoked.

Gellhorn's research shows that citizens' complaints account for more than eightyfive per cent of the Ombudsman's docketed cases, with newspaper stories and office inspection on his own initiative accounting for the remainder. ${ }^{16}$ While the complaints include a normal quota of "crank" letters that should be quickly discarded, many of these are examined carefully and given at least preliminary investigation so that the complainant will not feel rebuffed. The work of the Ombudsman's office is highly personalized. He reads the incoming complaints as they arrive and decides whether to request the official body involved to forward the applicable files to him. He conducts directly even informal conversations with officials, relegating only paper work to his staff. He and his staff appear to operate speedily and efficiently. Gellhorn reports, for example, that more than eighty per cent of the cases are disposed of within six months after docketing.

The Ombudsman's powers as an investigator are virtually unlimited. $\mathrm{He}$ has access to all official files and records, can interrogate any public official, and can-though hardly ever does-observe the deliberations of all courts and government agencies. He may choose to prosecute for violations or give "reminders" to errant bureaucrats. That only thirty-two punitive proceedings were instituted from I 960 through 1964 , whereas there were 1,220 reprimands and suggestions issued during the same period, shows a preference for reform through admonition. The admonitions are accompanied by reasoned opinions designed to educate the wrongdoer and to provide guidelines and resolve doubts for all officials in similar circumstances.

The power to prosecute or to admonish is not, of course, the same as the power to reverse decisions. The Ombudsman cannot order a decision changed or require formally the reopening or reconsideration of a judgment. The possibility that he may commence proceedings that can lead to rebuke, fine, or even removal from office, however, offers a strong incentive to officials to respond to the Ombudsman's

\footnotetext{
${ }^{16}$ Gellhorn, The Swedish Ombudsman, 75 YALE L.J. I, 10 (I965).

${ }^{10} 7 d$. at 15 .
} 
recommendations or reminders by correcting the particular injustice or breach of duty.

The institutions and areas covered by the Ombudsman's docket are impressively broad. They include alleged violations by judges, public prosecutors, police, prison administrators, hospital officials, school administrators, and tax authorities. Gellhorn has found that the administration of social insurance and other welfare state programs has not been a dominant element of the Ombudsman's caseload.

Of the complaints received, roughly ten per cent have been found to be justified by the time investigation has been completed. Of 1,4 ro docketed cases in 1964 , for example, 722 were dismissed after inquiry, $38 \mathrm{I}$ were dismissed without inquiry, 283 elicited "admonitions or other remarks" by the Ombudsman, and only two were prosecuted. ${ }^{17}$

The range and scope of the Ombudsman's inquiries are immensely helpful in keeping officials aware of their public accountability. His function as a "supervisory shadow" influences present official behavior, even though the probability of actual inspection by him is remote.

An important factor in the Ombudsman's role is the relationship of the press to his office. He has been traditionally a strong proponent of the newspapers' "right to know"; and the press serves as occasional critic, frequent source, and constant publicizer of the Ombudsman's findings. The Ombudsman's relatively small budget makes his impact on administration all the more remarkable. The entire operation, occupying half of the third floor of a small building in downtown Stockholm and staffed with three secretaries and from six to nine lawyers, is maintained at a cost roughly equivalent to $\$ 120,000$ a year. The Ombudsman's own salary is the same as that of a Swedish supreme court justice.

From a functional standpoint, the Ombudsman-at relatively low cost to the taxpayers-educates the citizenry and the bureaucracy about the processes of government. While placating the aggrieved citizen through speedy and thorough attention to the injustice alleged, the Ombudsman's carefully reasoned opinion is more likely to support than to reprimand the government official or agency involved. In the small proportion of cases in which wrongdoing is found, the Ombudsman's opinion and judgment help to formulate appropriate standards for administrators in many areas. The Ombudsman provides what a British observer views as the needed machinery "to handle complaints about the manner of the exercise of power by officials, to take them out of the political area and to investigate them dispassionately, without too much trouble or fuss." ${ }^{\text {"18 }}$ By expressing his opinions clearly and persuasively in a context that holds the promise of follow-up, he induces courts and administrators voluntarily to follow his recommendations. While his interpretations may certainly be rejected, "a certain presumption exists that these interpretations

\footnotetext{
${ }^{17} 1 d$. at 18.

${ }^{28}$ Henry W. R. Wade, Towards Administrative Justice I0I (1963). (Emphasis in original.)
} 
are correct. The annual reports of the Ombudsman are carefully studied as evidence of the law."18

Another significant function of the Ombudsman is his performance as "the generalist in a specialized world." Whether dealing at a typical time with an allegedly negligent chairman of the housing council, the chairman of a child welfare council charged with committing improperly a father who had been lax in contributing to his children's support, a public prosecutor for failing to inform the court that a state's witness had to his knowledge committed perjury, or an errant official of the National Board of Civil Aviation for accepting a free ride from an airline whose application for license renewal was pending with the Board, the Ombudsman's concern is less with the differential powers and needs of the governing structures involved than with the broadly applicable criteria of fair and equitable administration. Perhaps the most important achievement of the Ombudsman's office, according to one of its occupants, is that "its very existence prevents any number of faults and abuses of power."20

The combination of low cost and high popularity has accounted for adoption of the office of Ombudsman as a device for controlling the bureaucracy in Finland, Denmark, Norway, and, just recently, in New Zealand. The office is certainly not a captive of any particular form or structure of government. While Sweden and Finland have administrative courts in addition to the office of Ombudsman, Denmark and Norway do not. The fear that the Ombudsman idea would not work in common law countries is refuted by the initial achievement of the office in New Zealand. Professor Rowat evaluates the Ombudsman as "an important new addition to the armoury of democratic government" and predicts that the office or its equivalent "will become a standard part of the machinery of government throughout the democratic world." 21 Less sanguine but perhaps more realistic may be Professor Gellhorn's appraisal:

For one who thinks in American terms, the Ombudsman system seems a useful device for occasionally achieving interstitial reforms, for somewhat countering the impersonality, the insensitivity, the automaticity of bureaucratic methods, and for discouraging official arrogance. To rely on one man alone-or even on a few men-to dispense administrative wisdom in all fields, to provide social perspectives, to bind up personal wounds, and to guard the nation's civil liberties seems, on the other hand, an old-fashioned way of coping with the twentieth century. ${ }^{22}$

That the office of Ombudsman alone cannot cope with all the problems of the administrative state is hardly an adequate reason for arguing against its establishment as a supplement to other devices. There are factors, however, that could impair its utility for us. Perhaps the most serious is the fact that, no matter how

\footnotetext{
${ }^{10}$ Jägerskiöld, supra note 13 , at 1092-93.

20 The New Yorker, Feb. 13, I965, p. 140. Mr. Alfred Bexelius was Sweden's 3 Ist Ombudsman.

21 Rowat, op. cit. supra note 13 , at 292.

22 Gellhorn, The Swedish Ombudsman, 75 YALE L.J. I, 58 (1965).
} 
independent by tradition he appears to be, the Ombudsman is part of the establishment. The very element of nonpartisanship that surrounds his selection may be an assurance of relative innocuousness in the execution of his functions. His critique of petty or wayward individual bureaucrats could screen, however inadvertently, more significant failures on the part of the bureaucracy and establish the illusion for a lulled populace that all is well because the Ombudsman is on patrol. Without detracting from the high standards of public service in Scandinavian countries, it might be observed that the fiscal resources of the Ombudsman's office are so modest as to inhibit investigations that would discover and disclose major instances of incompetence or corruption. A single congressional investigation in the United States generally costs more than does the operation of the Ombudsman's office in Sweden for an entire year. ${ }^{23}$

Another limitation inherent in the office of Ombudsman, at least so far as the war on poverty is concerned, is that it ignores the desirability of participation by the people themselves in the processes of revision and reform. The relationship between Ombudsman and complainant is hierarchical, the Ombudsman exercising benevolence and discretionary intervention associated with eras of the "pukka Sahib" and "white man's burden." For our society, at least, institutional accountability, no matter how grudging, is preferable to institutional immunity, no matter how benevolent. Participation in the process of democracy, no matter how crass or grating, is preferable to alienation, no matter how genteel. Participation, to be meaningful, requires more than faith in officials or in the opinions of independent critics or watchmen of officials. Without minimal measures of accountability between citizens and officials, what passes for participation is in reality meretricious ritual.

To what extent do existing institutions in the United States for controlling the bureaucracy serve merely ritualistic functions? And to what extent do they in actuality or potentiality provide effective access to challenge, revision, and reform?

\section{JUdicial Review}

The basic appeal of judicial review as a means of controlling the bureaucracy is its combination of confrontation of officials by complainants and the capacity to order immediate halts to impending actions or to apply spurs to lethargic or reluctant bureaucrats. There are no devices more effective than the injunction and the writ of habeas corpus to counter governmental terrorism; and resort to mandamus can help to achieve responsible performance by administrators of official functions they would otherwise ignore or discard. The sine qua non of judicial review is not a third party's benevolence, as it must be in the case of the Ombudsman. In a court

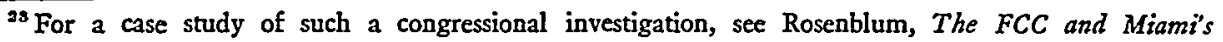
Channel 10, in The USES of Power 173, 192-219 (Westin ed. 1962).
} 
action, petitioner files his complaint as of right and the alleged offender must answer.

The problem of judicial review as a check on the bureaucracy is not found in its underlying theory, its objectives, or even its emergent doctrines; rather its problem is the practicality of access as complicated by the gaps and overlaps in judicial organization. On the whole, judicial review has produced procedurally tenable and substantively equitable standards for evaluating administrative action. The dangers inherent in early decisions-like Schechter Poultry, ${ }^{24}$ Panama Refining, ${ }^{25}$ Crowell $v$. Benson, ${ }^{26}$ and the first two Morgan cases ${ }^{27}$-that might have immobilized creativity or stifled imagination have been minimized in recent years. The courts have consistently shown their respect for administrative expertise, flexibility, and representation of the public interest. On the other hand, without embracing doctrinal formalism, the courts have often required administrative accountability. Such concepts as primary jurisdiction have been allowed neither to substitute judicial preferences for those of administrators nor make administrative action unreviewable. Through decisions like Isbrandtsen, ${ }^{28}$ the courts enhance agency expertise in marshalling facts and organizing them into meaningful patterns, while reserving to the judges the ultimate determination of questions of law.

There are notes of realism in recent perceptions of and admonitions to administrators by the judges. The significance attached to the state of an agency's backlog of cases in the "Catco" decision ${ }^{29}$ and the admonition to the Federal Power Commission in the Hunt case ${ }^{30}$ to study and perhaps emulate the National Labor Relations Board's procedures to help clear docket congestion are indicators of judicial understanding of the nuances of the administrative process. This is not to say, of course, that judicial review has ever been or is now the deus ex machina of our governmental system. Problems connected with standing to sue, indispensable parties, and unreviewable action have by no means been resolved, ${ }^{31}$ but administrative accountability without impairment of administrative flexibility has certainly been encouraged by the courts. A prototype of judicial decisions in this realm has been the Vitarelli case $^{32}$ in which the Justices of the Supreme Court agreed unanimously that executive agencies must be rigorously held to the standards by which

\footnotetext{
${ }^{24}$ Schechter Poultry Corp. v. United States, 295 U.S. 494 (I935).

${ }^{25}$ Panama Ref. Co. v. Ryan, 293 U.S. 388 (r935).

${ }_{28}^{26}$ U.S. 22 (I932).

${ }^{27}$ Morgan v. United States, 298 U.S. 468 (1936); Morgan v. United States, 304 U.S. I (r938).

${ }^{28}$ Federal Maritime Board v. Isbrandtsen Co., 356 U.S. 481 (1957).

${ }^{20}$ Atlantic Ref. Co. v. Public Serv. Comm'n of New York, 360 U.S. 378 (1959).

${ }^{30}$ Federal Power Comm'n v. Hunt, 376 U.S. 515, at 527 (1964).

${ }^{31}$ Davis treats the problems comprehensively in chapters 22 and 28 of his Administrative Law Treatises. For a detailed analysis of the strengths and weaknesses of the judiciary in coping with arbitrary agencies, see Berger, Administrative Arbitrariness and Judicial Reviev, 65 ColvM. L. Rev. 55 (1965). See also Byse, Proposed Reforms in Federal "Nonstatutory" Judicial Review: Sovereign Immunity, Indispensable Parties, Mandamus, 75 Harv. L. REv. 1479 (1962).

s3 Vitarelli v. Seaton, 359 U.S. 535 (r959).
} 
they profess their actions to be judged. Under this ruling, any agency remains free, consistent with the statutes governing it, to establish its own modus operandi but is required to follow it, once established, unless and until new procedures are adopted formally and prospectively. Justice Harlan's view seems especially apt. $\mathrm{He}$ observed that in proceedings

in which the ordinary rules of evidence do not apply, in which matters involving the disclosure of confidential information are withheld, and where it must be recognized that counsel is under practical constraints in the making of objections and in the tactical handling of his case which would not obtain in a cause being tried in a court of law before trained judges, scrupulous observance of departmental procedural safeguards is clearly of particular importance. ${ }^{33}$

These procedural guidelines for administrative action have, of course, had greater applicability to the work of the long-established agencies than to agencies concerned with implementing the poverty program. There is no reason, however, to oppose the application of these requirements to the work of the Office of Economic Opportunity, federal welfare agencies, and local and regional offices administering phases of the poverty program.

A key illustration of this potentiality was the California Supreme Court's landmark decision last year ruling that the Constitution's equal protection clause forbade the transfer to relatives of a mentally ill person the financial burden of care in a state institution. ${ }^{34}$ The California Department of Mental Hygiene had sued the estate of the child of a mentally ill mother to recover the cost of the mother's maintenance in a state hospital. The court ruled that, since the administration of laws providing treatment for the mentally ill is an appropriate state function, "a statute obviously violates the equal protection clause if it selects one particular class of person for a species of taxation and no rational basis supports such classification." ${ }^{35}$ As tenBroek has observed,

the principal cause of dependency is not individual but social, a need for protection arising from the complexities of modern society and the imperfections of a rapidly advancing economy. Since a major cause of poverty is social, over which the individual has no control, relief is a proper charge against the total economy. ${ }^{36}$

Even limited to state constitutional grounds, the Kirchner decision embodies a significant doctrinal innovation and plants seeds for further reconceptualization of welfare administration practices.

\footnotetext{
${ }^{33}$ Id. at 540 .

${ }^{36}$ Department of Mental Hygiene v. Kirchner, 6o Cal. 2d 716, 36 Cal. Rptr. 488, 388 P.2d 720, cert. granted, 379 U.S. 8 I I ( 1964 ). The U.S. Supreme Court remanded the case to the California Supreme Court for determination of whether the California court had relied on the federal or state equal protection clauscs. 380 U.S. $194\left(x_{965}\right)$. The California court subsequently ruled that it had relied on the state ground. 62 Cal. 2d 586, 43 Cal. Rptr. 329, 400 P.2d 32I (I965).

${ }^{35} I d$. at 722, 36 Cal. Rptr. at 492, 388 P.2d at 724.

${ }^{36}$ tenBrock, California's Dual System of Family Law: Its Origin, Development, and Present Status: III, I7 Stan. L. Rev. 6r4, 642 (1965). See also id., pts. I and II, I6 Stan. L. Rev. 257, 900 (1964).
} 
Vital though its functions may be, the judiciary still lacks the accessibility needed to assure equal justice under law for all. Viewed essentially as institutions through which the elite may resolve their conflicts with the bureaucracy or with one another, our courts have not until recently begun to serve as dispensers of justice to all the people. For the poor, courts have been too often the instruments through which aggressive creditors or vindictive police might demonstrate their power. The functions of courts as sources of redress of grievances of the poor were negligible, since so few could afford the fees of access to the mechanism. Even when the financial factor of access could be overcome with the help of legal aid offices or other devices, inadequate facilities, archaic rules, and problems of jurisdictional division among local courts have often necessitated prolonged litigation before a meaningful remedy could result. Typical of applicable criticisms were recent remarks of the chief justice of the Superior Court of Massachusetts castigating the denial of fundamental rights to persons "because of a shortage of judges, inadequate facilities, a lack of supporting personnel, and the failure of the bar and the legislature to promulgate modern rules of practice and procedure."37 Judge Tauro lamented the fact that state and local courts have the responsibility for their successful operation but not always the authority to carry out desirable programs. "In truth, the superior court is almost totally dependent on the legislature for its needs. ... The result is that many problems that could be nipped in the bud go unchecked until such time as the legislature can be convinced that remedial action is necessary." 38

As Purcell and Specht have pointed out in a recent issue of Social Work, redress sought by the poor can also be impeded by the division of authority among public agencies to which recourse must be had before suit can be brought. Even a grievance as specific as one relating to water supply may be subdivided so as to fall under several different jurisdictions. In New York until recently, they maintained, complaints about no water had to be referred to the Health Department; complaints about not enough water, to the Department of Water Supply; water overflowing from the apartment above, to the Police Department; and water seepage in the cellar, to the Sanitation Department. ${ }^{30}$

Delaying, stalling, dodging, and buck-passing have emerged under such circumstances as the deeds, if not the goals, of the society. Courts then serve as sanctifiers and institutionalizers of procrastination and perpetuators of the status quo, rather than as sources of accommodation to social need and as guardians of human dignity. Discovery of the feasibility of judicial reform has not been accompanied by its spontaneous generation. But this does not belie the fact that judicial review can protect, defend, and redress in behalf of the individual, while keeping a watchful -not necessarily jaundiced-eye on the bureaucracy.

\footnotetext{
${ }^{37}$ Tauro, Courts and Their Relationship to the Average Citizen, 49 J. AM. Jud. Soc'Y 58 (1965).

${ }^{38}$ Ibid.

${ }^{30}$ Purcell \& Specht, The House on Sixth Street, Social Work, Oct. 1965, p. 69, at 72.
} 
CONGRESSIONAL SUPERVISION

Extolling the virtues of Congress is hardly likely to replace baseball as the national pastime. More likely to meet public and academic approbation is the snide or sardonic critique of the legislature's defects. The complaints are legion and timeless, including

... the labyrinthine convolutions of the legislative process itself, where what comes out has no predictable relationship to what went in; the ironies and occasional absurdities of the seniority system; the virtually unassailable power positions which committee chairmen enjoy; the brokerage and horse trading which the Congressional leaders must employ to get anything positive done; the shabby moral tone which emanates from the Capitol. ${ }^{40}$

Despite such redolent allegations about congressional infirmities, a stark and classic truth remains: in Senator Henry Jackson's words, "at the very heart of the American system of government . . . is the principle and practice of Congressional review-the duty of the legislature to cross examine the powerful."41 Recognizing that Congress must strengthen its machinery for auditing through the committee system the actual accomplishments of executive programs, Jackson insists that the machinery must not substitute some outside individual or institution for the supervisory role of the congressman. He finds "no satisfactory substitute for members of Congress, particularly those on the key committees, personally involving themselves in the day-in and day-out pick and shovel work."42

The objective, if not always the product, of such direct and personal involvement is, as a noted political scientist contends, to carry the process of representation over into the bureaucracy. "And it may well be that the most abiding role of Congress in the years to come will be its service as a place where the needs of the bureaucracy are continually being balanced against the prevailing special interests in the community." 43 Because Congress controls the purse strings and forms the ultimate contours of legislation, the bureaucrat must take seriously every communication from or with a senator or representative. The oldtimers who serve traditionally as chairmen of the committees in charge of substantive legislation or appropriations for government departments frequently consider the agency officials either "birds of passage" or "their own servants." 4 This congressional control over awards and sanctions for officialdom can have chaotic effects on the bureaucracy in extreme form,

\footnotetext{
${ }^{40}$ Burnham, Has Congress a Future?, 197 The Nation 546 (1963), reprinted in CoNgressional REFORM xg-2I (Clark ed. xg65).

11 Jackson, Executives, Experts and National Security, in Staff of Subcomm. on Nat'L Security and International Operations of the Senate Comm. on Government Operations, 89th Cong., ist Sess., Conduct of National Security Policr: Selected Readings 76, 8x (Comm. Print i965). For analysis of the problems Congress faces when executive privilege is invoked, see Berger, Executive Privilege v. Congresssional Inquiry (pts. I-2), I2 U.C.L.A.L. Rev. 1044, 1288 (1965).

12 Jackson, supra note $4 \mathrm{r}$.

${ }^{13}$ Lowi, Preface, Legislative Polmtics U.S.A. at xix (Lowi ed. 1962). (Emphasis in original.)

"Id. at xviii.
} 
since it divides the loyalties of administrators between the executive and the legislature. Nothing inherent in the system requires that matters reach the extremity, however. The trading pattern that is inherent in the system-involving the congressional committee, the administrative agency, the executive, and one or more clientele groups-helps to channel or institutionalize the conflicts and assure maximum visibility of issues and policy choices for ultimate ratification by the public.

The "pick and shovel" work of Congress in supervising the operations of the bureaucracy of the poverty program has been broad and detailed. Subcommittees on the poverty program have kept officials of the Office of Economic Opportunity, as well as their regional and local associates, under persistent scrutiny and challenge through public hearings, private confrontations, and assorted jabs and jibes. That individual congressmen may sharpen political axes of their own through such practices must not obscure the fact that congressional hearings and investigations have provided a powerful impetus for accountability on the part of administrators.

Consider, for example, the work of the House Subcommittee on the War on Poverty. In the spring of 1965 , after four of its task forces had examined the administration of the poverty program in eleven cities, the chairman charged at the outset of the hearings in Washington on the program that political machines in many communities had organized "giant fiestas of patronage" in order, among other goals, "to feed their political hacks at the trough of mediocrity." He particularly criticized the Office of Economic Opportunity for "administrative overcentralization to the exclusion of independent groups" and for "obvious failure to carry out a most important objective: that of involving the poor in the war on poverty."

The transcripts of the hearings, although frequently verbose and repetitive, are noteworthy for their airing of immediate public problems in an environment of courtesy, challenge, and exhaustiveness. These excerpts from the questioning of Dr. Deton Brooks, who heads the program in Chicago, and of the Reverend Lynward Stevenson, President of The Woodlawn Organization and a strong critic of Dr. Brooks' administration of the poverty program, offer typical illustrations of the use of the congressional investigation to develop significant data and to bring conflicts into the open, channel them into peaceful avenues, and hold open the possibility of redress:

CONGRESSMAN CAREY OF NEW YORK. Dr. Brooks, would you answer a few brief questions on the type of projects you contemplate in Chicago? Are you establishing a credit union service?

Mr. BROOKS. It has not been funded yet but we contemplate it.

Mr. CAREY. We found this to be quite popular and somewhat effective here in the District.

Mr. BROOKS. It is almost necessary, that is right.

${ }^{45}$ Hearings on Examination of the War on Poverty Programs Before the Subcommittee on the War on Poverty Program of the House Committee on Edzication and Labor, 8gth Cong., Ist Sess. 2 (1965). 
Mr. CAREY. Secondly, do you intend to provide legal service, such as has not been available before?

Mr. BROOKS. Yes. We already have a proposal before the Office of Economic Opportunity for the Legal Aid Bureau of Chicago to provide those legal services in the urban progress centers.

Mr. CAREY. You are going to use the Legal Aid Bureau?

Mr. BROOKS. That is correct. No. $I$, it takes all influence out. It would be a relationship of client and attorney. In other words, once we get them funded they can handle that client just as if he were any other client. The one problem, and I understand that it has been worked out now, was a problem on the national level concerning American Bar Association policy.

However, at our local level we had no problem. Our Legal Aid Bureau in Chicago has been working in cooperation with the Chicago Bar Association over a long period of years. They have the competence and the technique. We certainly want them to handle these services for us.

Mr. CAREY. Of course, they are handling these things now where criminal defense is involved. But beyond that, landlord and tenant, in fact the broad span of legal representation, exclusive of domestic relations, will you engage in all these things?

Mr. BROOKS. Yes. Let me point this out, that if there is a relationship of a tenant to a person, to an individual person, in any way, that person deserves his day in court regardless. ... .

I was asked one day by a civil rights group what would happen if a landlord came and the tenant hit him in the mouth because their relationship had been so bad.

I said, we would give him legal aid because he deserves his day in court.

Mr. CAREY. Doctor, are you closely coordinated in your planning function with your department of public assistance or whatever counterpart you have, welfare department? Where is your cross-over or liaison there?

Mr. BROOKS. On every level. The Department of Public Aid has been a part of our total committee since its inception. No. 2, the Department of Public Aid in certain programs is taking responsibility for the training of all kinds of people, for instance in the homemakers' program.

No. 3, at the local level, at the urban progress center level, they have a liaison in every urban progress center that we have open....

Mr. CAREY. Have you any way in your planning, or do you intend in your planning, to gauge the success and effect of poverty activities by seeing the resultant effect upon your welfare roles and the number of people on assistance?

Mr. BROOKS. This would be one way. That will not be the only way, but this ought to be one measure that we should look at carefully.

Mr. CAREY. It is a highly important measure, because we sold this theory to the Congress on the theory we were going to phase out the dole and everything else, in order to make taxpayers out of tax-eaters. ...

We have an expression that was originated by a great public utility in New York, the Con-Edison Co., and all over our city are signs "Dig we must," and I think the slogan of our task forces must be to "Dig we must."

We must go to the roots of the program and see how the legislation is working in the minds of the poor. ... ${ }^{48}$

${ }^{16}$ Id. at $343-45$. 
The House Committee's probe of "the minds of the poor" produced some vehement condemnations of the program's administration. Reverend Lynward Stevenson's accusations against the Chicago Committee on Urban Opportunity were a typical case in point:

Mr. STEVENSON ... [T] The Woodlawn Organization has been conducting a Manpower Development and Training Act job-training program for the hardcore unemployed since July rg64. This program was funded directly to the people by the U.S. Department of Labor, the Office of Manpower, Automation, and Training.

We do not have any so-called social engineers on our staff. We have people in the community-poor people-who are the counselors, who know and feel with the people and stand side by side the unemployed no matter what the situation is. ...

The result is this: Our dropouts are a mere 20 per cent of the number enrolled. Ninety-eight per cent of our graduates have been hired for jobs. This is what the poor can do for themselves, given the chance, and we will continue to do this. This is self-determination. ...

Since October $\mathrm{r} 6_{4}$ we have been held at bay. Public criticism of the director of the Chicago Committee on Urban Opportunity for his reluctance to deal with the TWO has only resulted in defensive action on his part by holding a number of phony conferences with TWO, which began nowhere and ended nowhere. . . .

We are not children that must be planned for. We are not primitive savages that must be civilized by so-called civilized colonialists. Our retraining program stands as a beacon light to community organizations all over the country showing the way to what can be done by the poor themselves.

And yet, we have been meeting over and over with Deton Brooks, the director of Chicago Committee on Urban Opportunity, and all we have gotten is drivel. We have asked Deton Brooks for funds for a day care center and a medical care center, but he cannot talk sense. He speaks meaningless sociological drivel designed not to lift people but to keep them dependent. ${ }^{47}$

The conflicts between the Chicago Committee on Urban Opportunity and The Woodlawn Organization have by no means been resolved, but the visibility and confrontation afforded by the congressional hearing have reinforced the likelihood of settlement through peaceful political action. ${ }^{48}$ Thus, the significance of these and

\footnotetext{
${ }^{47}$ Id. at $346-47,359$.

48 The capacity of Congress to keep tabs on the bureaucracy of the poverty program and to provide outlets and channels for community dissensus has been demonstrated also by the Senate Subcommittee on Poverty. During its June 1965 hearings, for example, the Senate Subcommittee contributed with political finesse to the subsequent elimination of Sargent Shriver's dual roles and made officials of the OEO re-examine some policies in response to critics who had castigated the administrators of the program for alleged exclusion of the poor.

"Senator JAVITS. May I ask one question: I wondered if you could tell us how you are dividing your time now between the Office of Economic Opportunity and the Peace Corps?

Mr. SHRIVER. You know the gossip, Senator, that $I$ am in both places at the same time.

Senator JAVITS. Are you?

Mr. SHRIVER. Actually there is a lot more truth to it than there is joke to it. I frequently talk to men who are working with one operation or the other. They don't know in fact whether I am in one building or the other. Whether I am physically in one building I think:
} 
other illustrations of congressional supervision of the bureaucracy lies in the provision of effective opportunity for participation in and redress through the processes of government. Congress's financial resources and capacity for swift political action provide instruments for controlling the bureaucracy that are far more consistent with the nuances and complexities of twentieth-century government than Ombudsmen or administrative courts can provide.

In so far as the specifics of the Economic Opportunity Act are concerned, it is important to note that revisions in the statute have resulted from the hearings. Title two, dealing with the community action programs, for example, has been amended to require reasonable access by the public to information about programs

is not as important as to whether or not I am available adequately to the people who are working in the organization. They have been very kind so far. Nobody has said that I was unavailable. In fact, I think perhaps it is just the reverse. I am too available.

Senator JAVITS. You have no program as to division of time?

Mr. SHRIVER. Program division?

Senator JAVITS. Yes.

Mr. SHRIVER. No; I work all the time on both of them."

Hearings on Expanding the War on Poverty, Before the Select Subcommittee of the Senate Committee on Labor and Public Welfare, 89th Cong., Ist Sess. 123 (1965).

Dr. Reginald Hawkins of Charlotte, N.C. made a number of statements critical of the operation of the community action program in the South generally, and the Charlotte program in particular. Dr. Hawkins charged among other things that:

"Very few Negroes in the South have confidence in this war on poverty as it is presently constituted, staffed, and operated at the State and local levels. They see all the top paying jobs in administration going to white people who already had high-paying jobs. They also see the same people in leadership roles from the same old social departments and agencies that have kept them poor and dependent in the past."

Hearings, supra, at 239.

The OEO was confronted with the charge and reacted promptly in a memo to the Congressional Committee:

"We believe this statement should be considered in light of the following:

r. Every community action program in the South is either run by an organization with a biracial governing board, or has organized or is organizing a biracial policy committee program and responsibility.

2. Scores of key staff positions on local community action agencies in the South are filled by Negroes. The following are illustrative:

The deputy director of the Nashville, Tenn., program.

The organizer of the neighborhood services in Knoxville, Tenn.

The head of the Clarksdale, Miss., Head Start Program.

The associate director of the Savannah, Ga., Chatham County program.

The coassociate director of the Atlanta-Fulton County program.

The assistant director of the Dade County, Fla., program.

The associate director of the Jacksonville, Fla., program.

The coassistant director of the Winston-Salem, N.C., program.

The assistant director of the Durham, N.C., program.

The assistant director of the Corinth, Miss., program.

3. Predominantly Negro institutions such as Mary Holmes Jr. College, Paine College, Tuskegee Institute and Alabama A. \& M. are playing important roles in the program.

4. Without question, the Negro in the South is participating more extensively and more intensively in their program than he has in any other whether under Federal, State, or local auspices."

Hearings, supra, at $24 \mathrm{x}$. 
and policy, including reasonable opportunity for public hearings and access to books and records of agencies administering the programs. ${ }^{49}$

Congressional vanity and banality may, of course, triumph over nobler motives, but our system of checks and balances, by countervailing the ambitions and powers of one branch with the ambitions and powers of the others, limits even those congressmen prone to blatant demagoguery in efforts to control the largesse of government.

\section{Perspectives on the Problem of Control}

Determination of preferences or priorities from among the devices for controlling the bureaucracy depends in considerable part upon our objectives and aspirations. Are we seeking merely the substantive manifestations of deeds of justice or do we aspire as well toward an administrative process that maximizes participation and the stake of every individual in the mechanisms of government? If we focus on deeds of justice alone, then selection and enhancement of the Ombudsman's role offer suitable means for assuring good deeds. But if participation in the processes of government is important as well, then emphasis must be placed on the controls that heighten participation.

What significance do we attach to political participation, with all its caviling and inefficiency, as a vital component of democracy? There can be little doubt that the Economic Opportunity Act was designed to strengthen, supplement, and coordinate opportunities for participation as well as for education, training, and employment. $^{50}$ There is some disagreement among scholars, however, over whether we should be content to keep a substantial segment of the population in a state of political inertia and vacuity. Froman's research in voting behavior in congressional elections, for example, shows that the greater the percentage of non-white population, the smaller the voting turnout; and the smaller the percentage of owner-occupied dwelling units, the smaller the voting turnout. ${ }^{51}$ Berelson, Lazarsfeld, and McPhee in their study of voting have maintained that such examples of political apathy promote the likelihood of political stability. According to their view, the larger the number of intense losers in a political contest, the greater the possibility that the losers can be mobilized into ad hoc undemocratic groups. Perhaps we have to accept the view that economically poorer, less educated people in the United States are less likely to participate and more likely to have authoritarian values than those from the better educcated middle and upper classes. ${ }^{62}$

\footnotetext{
${ }^{\circ 0}$ Economic Opportunity Amendments of $1965, \S \mathrm{II}(5), 79$ Stat. 974, 42 U.S.C.A. $\$ 2782$ (5) (Supp. 1965). See Fouse Comm. on Educ. \& Labor, Economic Opportunity Amendments of 1965, H.R. REP. No. 428,89 th Cong., Ist Sess. 7-II (I965).

${ }^{50} 78$ Stat. 508, 42 U.S.C. $\$ \$ 270 \mathrm{r}-98 \mathrm{r}(1964)$. The community action programs authorized by title II, part A, are explicitly designed "to provide stimulation and incentive for urban and rural communities to mobilize their resources to combat poverty ... ." 78 Stat. 5x6, 42 U.S.C. $\$ \$ 278 x-82$ (1964). See generally Cahn \& Cahn, The War on Poverty: A Civilian Perspective, 72 Yale L.J. I3I7 (1964).

"iz Lewis A. Froman, Congressmen and their Constituencies 37 (1963).

${ }^{52}$ Bernard R. Bereison, Voting ch. $\mathrm{I}_{4}(1964)$; Seymour M. Lipset, Political Man 32 (1960).
} 
Data like these lead such students of political behavior as Lester Milbrath to "doubt that the society as a whole would benefit if intense interest and active involvement in politics became widespread throughout the population."53 On the other hand, Milbrath recognizes, along with Almond and Verba, that it is valuable to admonish citizens to become active in politics because "the belief in the influence potential of the average man has some truth to it and does indicate real behavioral potential."54

There is other evidence, however, that citizen competence and citizen participation reinforce one another. Herbert McClosky presents data in support of the proposition "that whatever increases the level of political articulateness-education, S.ES. [socio-economic status], urban residence, intellectuality, political activity, etc.strengthens consensus and support for American political ideology and institutions." ${ }^{35}$ He finds that the politically unsophisticated have difficulty "discriminating political integrity from demagoguery, maturity and balanced judgment from fanaticism, honest causes from counterfeits." ${ }^{\text {"56 }}$ In short, those with the least understanding of American politics subscribe with the least enthusiasm to its principles. Democratic ideology grows as the articulate class grows.

Relating these observations to the poverty program, it would appear that those deeds of the bureaucracy that constitute merely charitable handouts to people enlarge a sense of alienation rather than of participation, just as voting for a particular candidate because one has been given a bottle of liquor or a five dollar bill to do so denigrates the political process. ${ }^{57}$ Deeds that are the product of participation, on the other hand, instill a commitment to the processes and institutions that engender them. We must seek through the poverty program and the controls we place over it, therefore, to bolster and multiply the factors that make people articulate and increase their participation. The poor have been one of the "forgotten groups," or "those who suffer in silence," because, until recently, they have had neither opportunity nor incentive to organize, to establish lobbies, or to take action. ${ }^{58}$ Our objective in increasing participation is not to create a bureaucracy of the poor to countervail the bureaucracy of the poverty program, but rather to fortify the ideology of democracy. Professor Edelman has pointed out that "our political institutions constitute, among other things, a device for providing symbolic

\footnotetext{
${ }^{83}$ Lester W. Milbrate, Political Participation 147 (1965).

os Gabriel. A. Almond \& Sidney Verba, The Civic Culture 487 (1963); Milbrath, op. cit. supra note 53 , at 152 .

${ }^{65}$ McClosky, Consensus and Ideology in American Politics, 58 AM. PoL. Scr. Rev. 36r, at 362 (1964).

so Id. at 379.

"T Professor Reich, op. cit. supra note 3, has developed the idea of "entitlement" in evaluating the deeds of government. He maintains that when an individual lacks sufficient resources to live decently, society has the obligation to provide him with support and the individual has a right to that support. Reich does not appear worried that entitlement in the absence of leadership or participation in policy formation by the poor themselves would necessarily reduce them to a supine mass.

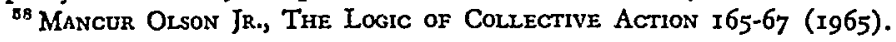


reassurance to threatened groups, and the device works admirably for most issues."

How can we provide institutions for the poor that reassure, not only symbolically, but through concrete involvement in institutional processes of innovation and change? Fuller's espousal of a central, indisputable principle of substantive, natural law offers at least a starting point. He says, "open up, maintain, and preserve the integrity of the channels of communication by which men convey to one another what they perceive, feel, and desire."60 There are no more apt institutions for this purpose than political parties, legislatures, and courts. Traditionally they were designed as devices for access to redress and reform, and no devices superior to these have yet been evolved. That they are themselves often inadequate in performing this role is an argument not for their rejection and replacement but for the continuing drive to improve them. We considered earlier some of the actions taken by Congress to encourage broader access to the policy-making process. Recent developments in law and social work provide additional reasons for optimism over the potentiality of our institutions to raise not only the substantive standards but the commitments to democracy of the poor. ${ }^{61}$

In social work, for example, there has been recent emphasis on the nature of social conditions that provide the context for individual responses. "It is important that the social work profession no longer regard social conditions as immutable and a social reality to be accommodated as service is provided to deprived persons with an ever increasing refinement of technique." 62 Part of the social worker's professional function, according to this view, is to seek solutions to social problems through institutional and organizational change, rather than merely to focus on individual problems in an accepted social setting. Kahn has described this kind of development as a combination of "a policy and a case approach." Examining the relationships between social work and the control of delinquency, Kahn finds, for example, that "social workers have traditionally been concerned more with diagnosis than with legalities, yet the misuse of the authority system when there is no basis for so doing is as much a diagnostic error as an infringement on rights." He admonishes the social work profession to give high priority to the development of coordinated programs and services that can convert such social labels as "delinquency" from a "differential instrument of social control to a social category for special services or help."

For social workers to limit themselves to case measures ignores the degree to

\footnotetext{
${ }^{5}$ Murray Edelman, The Symbolic Uses of Politics 770 (1964).

${ }^{\circ 0}$ LoN L. Fuller, The Morality of Law 186 ( 1964 ).

"These standards are conditioned essentially on the assumption that institutionalized social conflict benefits the flexible society. As Coser has said, "In loosely structured groups and open socictics, conflict which aims at a resolution between antagonists is likely to have stabilizing and integrative functions for the relationship." Lewis A. Coser, The Functions of Social Conflict 154 (1956).

¿2 Purcell \& Specht, supra note 39 , at 75.

${ }^{\circ 8} \mathrm{Kahn}$, Social Work and the Control of Delinquency: Theory and Strategy, Social Work, April 1965 , p. 3 , at $\mathrm{r}_{3}$.
} 
which the client's problem belongs to the community and society as well as to the individual, family, or peer group. No longer need social work be an instrument conducive to resignation, apathy, and adjustment to poverty in perpetuity. It can become in large part an "enabler," to use Grosser's term, by teaching clients that solutions to many of their problems lie in the hands of governmental agencies and that the agencies are sensitive to citizen efforts, especially in election years. This has been the approach of organizations like Mobilization for Youth whose focus has been on achieving social change through community action. ${ }^{64}$ Frustration and isolation can thus be channeled into constructive efforts toward redress and reform through these additional dimensions of the social work profession.

If this newer orientation of social work functioned in a vacuum, it would be of limited value. Its special significance lies in its development concomitantly with "the law explosion" of the I960s. That some roles in any social system receive more rewards than others does not mean that the "differential distribution of sanctions in society" ${ }^{15}$ need remain static. Law, through its implementation of access to the ruleenforcing machinery of the society, can make material and explicit what might otherwise remain ineffable aspiration. The law explosion has, in fact, put this issue in the forefront of agenda items for academic groups, civic betterment organizations, and bar associations.

Commenting on the confrontation by the courts of the mid-century law explosion, Harry Jones notes that "new social interests are pressing for recognition in the courts. Groups long inarticulate have found legal spokesmen and are asserting grievances long unheard. Each of these developments has brought its additional grist to the mills of justice."

It would be premature, if not fatuous, to claim that legal facilities are adequate to meet the demands on them, but several developments connote sufficient progress to warrant enthusiasm for the possibility of long-range resolution. The growth of neighborhood law programs in New York, New Haven, Boston, Oakland, Washington and other cities has been the product of new conceptions of legal aid. "Persons in need of assistance from legal aid offices can find them not only closer to home but better financed and more adequately manned than ever before. ${ }^{67}$ The

\footnotetext{
ot Grosser, Community Development Programs Serving the Urban Poor, Social Work, July 1965, p. 15. In similar vein, Robert L. Kahn and Daniel Katz in a paper delivered at the 1965 Forum of the National Conference on Social Welfare urged social workers to acknowledge the importance of and attempt to utilize "direct systematic change-changes which involve altering formal procedures, policies, and structural arrangements." Kahn \& Katz, Social Work and Organization Change, in Proceedings of the National Conference on Social Welfare 162, i81 (1965). The January I966 issue of Social Work contains three other significant articles related to this theme: Waterman, Local Issues in the Urban War on Poverty, p. 57; Shostak, Promoting Participation of the Poor: Philadelphia's Antipoverty Program, p. 64; and Piven, Participation of Residents in Neighborlhood Community Action Programs, p. 73. Rien and Riessman propose a "third party stance aimed at increasing the demand for services by the poor" in A Strategy for Antipoverty Community Action Programs, Social Work, April 1966, p. 3 .

${ }^{65}$ Neil J. SMelser, The Sociology of Economic Life 39 (I963).

${ }^{o s}$ Harry W. Jones, The Courts, the Public, and the Law Explosion 2 (ig65).

"Patricia Wald's chapter on "Broadening Legal Assistance to the Poor" in her working paper, LAw and Poverty, 1965, Report to the National Conference on Law and Poverty (1965).
} 
development of group legal services, which are less likely than legal aid to bear the stigma of charity, facilitates collective action to ease the transition from poverty to self-sufficiency. ${ }^{68}$ That these programs often call for integration of the skills of lawyers and social workers both in making people aware of their legal rights and in providing access to legal services is another positive factor, since it cultivates social perspectives in lawyers and helps make social workers aware of the nature and function of the legal system. ${ }^{69}$ The growth of legal services within existing institutions avoids labeling the poor as such and enhances the belief in one system of justice for all. ${ }^{\text {70 }}$

To the growth of facilities and the integration of professional services should be added the increase in numbers of students being trained in the law and the revision in law school curricula so as to attune students to community needs beyond those of commerce and business. ${ }^{71}$

Involvement of representatives of bar associations in examining the work of the bureaucracy is another salient development. Too often in the past even the best-intentioned professional associations could do little to check the bureaucracy because of inevitable time lapses between the initiation of government action and the occasion to review it. Recent action by the Board of Governors of the American Bar Association authorizing its Section on Administrative Law to participate in matters affecting agency rules of practice and procedure is a small but significant step in narrowing the time gap. Visibility to unfair or improvident procedures can now be obtained in sufficient time to keep interests from vesting and backs from arching when criticism is voiced. ${ }^{72}$ In essence, then, we are witnessing progress in the implementation of Fuller's admonition to enlarge the channels of communication through which men convey their perceptions, feelings, and desires.

\footnotetext{
${ }^{68}$ Id. at 82-85. See also Doverman, Legal Services for the Poor, in Proceedings of THE 1965 NAtional Conference on Social Welfare 96 ( 1965$)$.

${ }^{a s}$ See The Lawyer and the Social Worker, in Proceedings of THE CONFERENCE on t7te Extenston of Legal Services to the Poor 133 (I965). See also Isaac, Law and Social Welfare, in Proceedincs of the 1965 National Conference on Social Welfare 3, 13-15; Katz, The Lawyer and the Caseworker: Some Observations, 42 Soctal CASEWORK 10-15 (1961); Mueller \& Murphy, Communication Problems: Social Workers and Lawyers, Social Work, April 1965, p. 2; McRac \& Linde, Lawyers and Social Workers: An Emerging Joint Venture, 48 J. AM. Jud. Soc'x 231 (1965).

${ }^{70}$ Pincus, The Law and Family Relationships, in Proceedings of the National Conference on SOCIAL WeLFARE 78-79 (I965).

71 The ferment in legal education is in good measure the work of the Association of American Law Schools. See The Role of Law Schools in the Extension of Legal Services, in Proceedings of THe National Conference on the Extension of Legal Services to the Poon 165 (1965); Wald, op. cit. supre note 67, at 89-94. Ferment in legal education, encouraged by the Association of American Law Schools, by innovations in the curricula of leading law schools, and by research grants from such foundations as Russell Sage, Walter E. Meyer, and Ford is adding new dimensions of intercst and concern to legal publications. The Yale Law Journal staff's comment, Participation of the Poor, 75 YALE L.J. 599 (1966), and the Columbia Law Review staff's comment, Citizen Participation in Urban Renewal, 66 ColuM. L. REv. 485 ( 1966 ) are prototypes of the trend.

${ }^{72} 18$ AD. L. REv. 5-6 (1965).
} 


\section{Conclusion}

Underlying this evaluation of devices to supervise the bureaucracy of the poverty program has been the assumption that control should be consistent with efficacy. Maximization of control without regard to efficacy would make the program a parody. The concern with efficacy has a dual aspect, too: it requires substantive achievement in helping to raise the living standards of the poor; but it also requires enlargement of opportunity for meaningful participation in the processes of government.

Holt has pointed out that "there is a certain minimal level of consensus that is required by any society. If the increase in dissensus exceeds this limit, the society will cease to function."73 Mere handouts may raise living standards but still contribute to dissensus. Programs that demonstrate the responsiveness of government to citizens' actions, on the other hand, reinforce the institutions and processes of democracy and thereby reduce the servility and alienation that are handmaidens of dissensus.

We have seen that judicial review and congressional supervision can be instrumental in presenting opportunities and outlets for citizen expression. In establishing priorities for action, we should place our emphasis on improving these indigenous mechanisms, rather than on importing devices that place more of a premium on charity than on stimuli to participation. The Ombudsman would be a useful addition to our politico-legal system of control, but the positives of its office would become negatives if it were to become a substitute rather than a supplement. The argument applies as well to specialized administrative courts. Gradual infusion of our legal system with specialized bodies modeled on the Conseil d'État could be beneficial, but not if they were to divert us from the current focus on bringing "equal justice under law" within the range of every man through reforms in judicial administration and accessibility of counsel.

Judge Harold Leventhal reminded us recently that the growth of law in the administrative process has been characterized by imposition of the restraints of checks and balances, curbs against excesses of government power, and evolution of fair procedures for decision-making. "Administrative law represents the effort of a democratic society to preserve liberty while new instruments of government evolve to deal with new problems and needs created by the industrial revolution."74 Efficacy and fairness, substantive reform and regard for due process are inseparable in societies that aspire to democratic achievement and continuity. ${ }^{75}$

\footnotetext{
${ }^{73}$ Holt, A Proposed Structural-Functional Framework for Political Science, in Don MARTINDaLE, Functionalisar in the Social Sciences ro4 (American Academy of Political and Social Science Monograph No. 5, 1965).

${ }^{74}$ Leventhal, Public Contracts and Administrative Law, 52 A.B.A.J. 35 (I966).

${ }^{75}$ This, perhaps, is what Lindblom means when he says in his discussion of the values of partisan mutual adjustment: "A democratic political system is one in which values are in some sense democratic and is not simply one in which values are democratically reconciled." Chardes E. Lindblon, The INTELLigenCE OF DeNociracy 315 (1965).
} 
The key aspect of the poverty program is its manifold opportunities. It offers to the poor the economic opportunity to rise from the debilitating morass of deprivation and dependency. It offers to the legal profession the opportunity to demonstrate the capacity of law to satisfy "the claims and demands and expectations involved in the existence of civilized society." opportunity to demonstrate to the world that the problems of all men are relevant in framing the policies of the democratic state and that the participation of all menhowever time-consuming, contentious, and abrasive-is not only welcome but indispensable in confronting the problems of our time.

\footnotetext{
${ }^{78}$ Pound, op. cit. supra note $I$, at 47 .
} 